\title{
Potentiality of Diethylamine as Agent of Deproteination and Deacetylation in the Extraction of Chitosan from Scylla serrata Shell
}

\author{
V. N. Okafor ${ }^{1 *}$, C. M. Umenne ${ }^{1}$, B. I. Tabugbo ${ }^{1}$, C. P. Okonkwo ${ }^{1}$, J. N. Obiefuna ${ }^{1}$, U. W. Okafor ${ }^{2}$, R. I. \\ Anyalebechi $^{3}$ \\ 1. Department of Pure and Industrial Chemistry, Nnamdi Azikiwe University, Awka, Nigeria \\ 2. National Board for Technology Incubation, Federal Ministry of Science and Technology, Abuja, Nigeria. \\ 3. Department of Science Laboratory Technology, Federal Polytechnic, Oko, Anambra State, Nigeria \\ ${ }^{*}$ Email of the corresponding author: vnw.okafor@unizik.edu.ng, +2348067965292
}

\begin{abstract}
The potentiality of diethylamine as deproteination and deacetylation agent in the extraction of chitosan from Scylla serrata (giant mud crab) shell was investigated. The aim was to find an alternative agent to inorganic alkalis as possible replacement for use in the production of high quality chitosan with the right stability. Pretreatment of the shell was carried out and followed by demineralization using hydrochloric acid. Diethylamine was used for deproteination and deacetylation by modifying some published protocols. Moisture, ash, fat and protein contents of the extracts were determined using their respective standard methods. Fourier Transform Infrared (FTIR) technique was used for spectroscopic analysis. Scylla serrata shell was composed of $14.25 \%$ protein, $32.84 \%$ mineral $\left(\mathrm{CaCO}_{3}\right)$, $31.52 \%$ chitin and $21.39 \%$ chitosan. Moisture, ash, fat and protein contents of chitin extracted from Scylla serrata shell were $2.35 \%, 3.03 \%, 1.79 \%$ and $3.85 \%$ respectively while those of chitosan were $1.65 \%, 3.84 \%, 0.53 \%$ and $2.80 \%$ respectively. Degree of deacetylation (DDA) and carbon to nitrogen ratio were $69.24 \%$ and 5.67 respectively. FTIR spectra of the extracted chitin and chitosan from Scylla serrata showed the presence of some active compounds of carbonyl, amide, amine and hydroxyl groups. However, $\mathrm{CH}_{3}$ waging along chain $\left(952 \mathrm{~cm}^{-1}\right), \mathrm{CO}$ stretching at $1026 \mathrm{~cm}^{-1}$ and $1073 \mathrm{~cm}^{-1}$, and amide II band $\left(1563 \mathrm{~cm}^{-1}\right)$ were not found in the extracted chitin while $\mathrm{HPO}_{4}{ }^{2-}$ and amide III were also not found in the extracted chitosan. These moieties were present in the standard chitin and chitosan respectively. This study has shown that diethylamine (organic base) has great potential as agent of deproteination and deacetylation in the extraction of chitosan from Scylla serrata. Consequently, academic activity in the area of investigation of the stability of the extracted chitosan from Scylla serrata using diethylamine as deproteination and deacetylation agent is strongly recommended.
\end{abstract}

Keywords: Diethylamine, deproteination, deacetylation, chitin and chitosan, Scylla serrata shell.

DOI: $10.7176 / \mathrm{CMR} / 12-7-07$

Publication date:October 31 st 2020

\section{Introduction}

Chitin also known as poly $\beta$ - $(1 \rightarrow 4)-\mathrm{N}$-acetyl-D-glucosamine (Figure 1$)$ is a natural polysaccharide which is biocompatible, biodegradable and bio-absorbable with antibacterial ability was discovered in 1811 by Henri Braconnot who named it fungine (Jeuniaux, 1996). It was Odier who found the same material in 1823 and named it chitin (Muzzarelli and Muzzarelli, 2009). This biopolymer is synthesized by enormous number of living organisms (Rinaudo, 2006). It belongs to the most abundant natural polymers, after cellulose. In the native state, chitin occurs as ordered crystalline microfibrils which form structural components in the exoskeleton of arthropods or in the cell walls of fungi and yeast. So far, the main commercial sources of chitin are crab and shrimp shells (Younes and Rinaudo, 2015).

In industrial processing, chitin is extracted by acid treatment to dissolve the calcium carbonate followed by alkaline solution to dissolve proteins. In addition, a decolourization step is often added in order to remove pigments and obtain a colourless pure chitin. All those treatments must be adapted to chitin source, owing to differences in the ultrastructure of the initial material to produce first a high quality chitin. Chitin is infusible and sparingly soluble during transformation into different conformations. The question of its solubility is a major problem in the development of both processing and use of chitin as well as its characterization. 


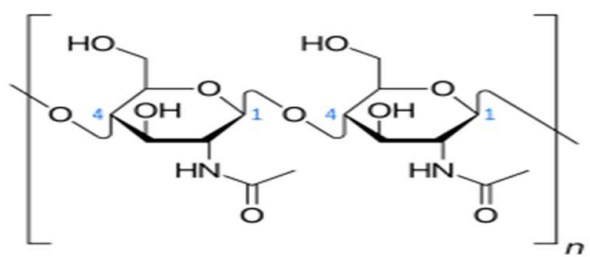

Figure 1. Chemical structure of chitin

(Lertsutthiwong et al., 2002)

Chitin has more applications while transforming to chitosan (Rinaudo, 2008; Rinaudo, 2012; Rinaudo, 2014). Chitin is a natural polymer as well as biocompatible and biodegradable in the body, thus widely used for biomedical and pharmaceutical applications. Additionally, good film forming properties are valuable for wound dressing, artificial skin or packaging.

Chitosan (Figure 2) is a natural multifunctional polysaccharide and due to its biocompatibility, biodegradability, and mucoadhesiveness has been extensively studied for a number of biomedical, agricultural, polymeric, engineering and pharmaceutical applications, including prolonged or controlled release drug delivery systems (Szymańska and Winnicka, 2012), wound dressings (Hurler and Škalko-Basnet, 2012), blood anticoagulants (Okamoto et al., 2003), cartilage and bone tissue engineering scaffolds (Kim et al., 2008; Venkatesan et al., 2014) and space filling implants (Hoemann et al., 2005). Chitosan is a polycationic copolymer, consisting of glucosamine and $\mathrm{N}$-acetylglucosamine units, obtained by deacetylation of chitin derived from the exoskeleton of crustaceans, insects, or fungi (Dash et al., 2011; Ifuku, 2014). It is available in a wide range of degrees of deacetylation and molecular weight, which are also the main factors influencing the nature and quality of the polymer (Szymańska and Winnicka 2015).

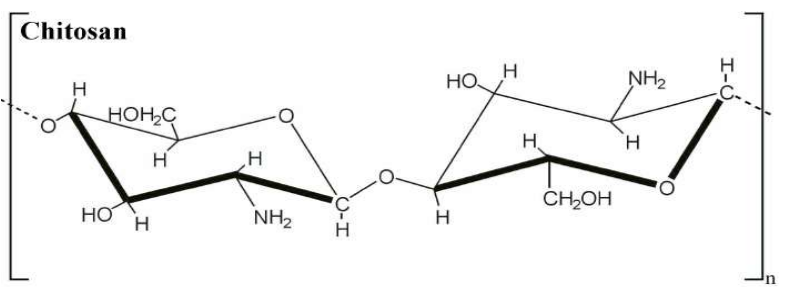

Figure 2. Structure of chitosan

(Lertsutthiwong et al., 2002)

Chitin is isolated from the exoskeletons of crustaceans, molluscs, insects and certain fungi, but the main commercial sources of chitin are crab and shrimp shells (Rinaudo, 2006; Al Sagheer et al., 2009). Depending on the source, chitin occurs in two allomorphs, the $\alpha$ and $\beta$-forms, and additionally as $\gamma$-chitin, which appears to be a combination of the $\alpha$ and $\beta$ structures rather than a different allomorph (Roberts, 1992). $\alpha$-Chitin is by far the most abundant and is usually isolated from the exoskeleton of crustaceans, particularly from shrimps and crabs. $\beta$-Chitin can be extracted from squid pens, and $\gamma$-chitin from fungi and yeast (Campana-Filho, 2007). $\beta$-Chitin is easily converted to $\alpha$-chitin by alkaline treatment followed by flushing in water (Noishiki et al., 2003). The description and interpretation of the infrared spectra of these two forms of chitin have been published by many scientists (Honarkar and Barikani, 2009; Pearson et al., 1960; Brunner et al, 2009). For example, the spectra of $\alpha$ - and $\beta$ chitin after $\mathrm{NaOH}$ treatment and $\mathrm{H}_{2} \mathrm{O}_{2}$ purification displayed a series of narrow absorption bands, typical of crystalline polysaccharide samples. The $\mathrm{C}=\mathrm{O}$ stretching region of the amide moiety, between 1700 and $1500 \mathrm{~cm}^{-}$ 1 , yields different signatures for $\alpha$ - and $\beta$-chitin. For $\alpha$-chitin, the amide I band was split into two components at 1660 and $1630 \mathrm{~cm}^{-1}$ whereas for $\beta$-chitin it was at $1630 \mathrm{~cm}^{-1}$ only. This is as a result of hydrogen bonding or the presence of an enol form of the amide moiety (Pearson et al., 1960; Brunner et al., 2009; Focher et al., 1992). The amide II band was observed in both chitin allomorphs: at $1558 \mathrm{~cm}^{-1}$ for $\alpha$-chitin and $1562 \mathrm{~cm}^{-1}$ for $\beta$-chitin (Brunner et al., 2009). Another characteristic marker is the $\mathrm{CH}$ deformation of the $\beta$-glycosidic bond. The band shifted from $890 \mathrm{~cm}^{-1}$ in $\beta$-chitin to $895 \mathrm{~cm}^{-1}$ in $\alpha$-chitin. Infrared spectra of $\beta$-chitin revealed two additional bands for $\mathrm{CH}_{\mathrm{X}}$ 
deformations at about 1455 and $1374 \mathrm{~cm}^{-1}$ and a greater number of narrower bands in the $\mathrm{C}-\mathrm{O}-\mathrm{C}$ and $\mathrm{C}-\mathrm{O}$ stretching vibration region (1200-950 $\mathrm{cm}^{-1}$ ) which was not observed in $\alpha$-chitin (Kumirska et al., 2010).

FTIR spectroscopy has been used to characterize not only isolated chitin (Brunner et al., 2009) but also the source of chitin, e.g., in two species of black coral, Antipathes caribbeana and A. pennacea (Juárez-de la Rosa et al., 2007). Although FTIR absorption spectra of the natural samples (without deproteinization) showed similar distribution patterns for both species of coral, and confirmed the presence of chitin in both species, small differences were observed (e.g., the intensity of the IR absorption bands in A. caribbeana was stronger). The absence of a free hydroxyl in the hydroxymethyl groups $\mathrm{CH}_{2} \mathrm{OH}$ in A. caribbeana indicated that the chitin chains were organized in sheets, where they were hydrogen-bonded to adjacent chains, a situation that favours a denser fiber packing of chitin. Limam et al. (2011) deproteinated chitin from two crustacean by-products with $\mathrm{NaOH}$ and deacetylated the extract to obtain chitosan. On FTIR analysis, they found that the shrimp chitin showed an intense peak at $1552 \mathrm{~cm}^{-1}$ which corresponded to the N-H deformation of amide II (Duarte et al., 2001; Ravindra et al., 1998). The bands at $1618 \mathrm{~cm}^{-1}$ and another at $1651 \mathrm{~cm}^{-1}$ are attributed to the vibrations of the amide I band, and the band at $1651 \mathrm{~cm}^{-1}$ corresponds to the amide I stretching of $\mathrm{C}=\mathrm{O}$. The band at $1618 \mathrm{~cm}^{-1}$ was attributed to the stretching of $\mathrm{C}-\mathrm{N}$ vibration of the superimposed $\mathrm{C}=\mathrm{O}$ group, linked to $\mathrm{OH}$ group by $\mathrm{H}$ bonding. These bands were clearly observed in all their samples. The sharp band at $1374 \mathrm{~cm}^{-1}$ corresponds to a symmetrical deformation of the $\mathrm{CH}_{3}$ group, and at $1552 \mathrm{~cm}^{-1}$ corresponds to the $\mathrm{N}-\mathrm{H}$ deformation of amide II (Duarte et al., 2001; Ravindra et al., 1998). They noted that for chitosan, the band at $1552 \mathrm{~cm}^{-1}$ has a larger intensity than at $1652 \mathrm{~cm}^{-1}$, which suggests effective deacetylation for the two species. The authors noted that when chitin deacetylation occurs, the band observed at $1652 \mathrm{~cm}^{-1}$ decreases, while a growth at $1552 \mathrm{~cm}^{-1}$ occurs, indicating the prevalence of $\mathrm{NH}_{2}$ groups (Bordi et al., 1991).

Furthermore, the FTIR spectra for chitin and chitosan extracted from mussel cuticle by Abdulkarim et al. (2013) gave characteristics bands of $-\mathrm{NH}_{2}$ at $3447 \mathrm{~cm}^{-1}$ and carbonyl group band at $1477 \mathrm{~cm}^{-1}$. They noted that the frequency ranges for the different classes of carbonyl compounds overlap, and that the carbonyl frequency alone is not sufficient to characterize the functional group as noted by Coates (2000) and yet they opined that the mussel cuticle can be used as a raw material for chitin and chitosan extraction.

Several techniques to extract chitin from different sources have been published (Roberts, 1992; Synowiecki and Al-Khateeb, 2003; Struszczyk, 2002). Crustacean shells consist of proteins (30-40\%), calcium carbonate (30$50 \%$ ), chitin (20-30\%) and pigments (astaxanthin, canthaxanthin, lutein or $\beta$-carotene). These proportions vary from species to species and from season to season (Aranaz et al., 2009). The most common method for chemically isolating chitin from crustacean shells involves a number of major steps: the washing, grinding and sieving of raw shells, followed by their demineralization (elimination of calcium carbonate in dilute acidic solution) and deproteination in aq $\mathrm{NaOH}$ or $\mathrm{KOH}$. The use of enzymatic hydrolysis for deproteination and microorganisms for both demineralization and deproteination has been also reported (Synowiecki and Al-Khateeb, 2003; Shirail et al., 998).

Industrially chitin is converted into the more readily applicable chitosan by partial or complete deacetylation of chitin in both the solid (heterogeneous process) and dissolved (homogeneous process) states under alkaline conditions or by enzymatic hydrolysis (using a chitin deacetylase) as shown in Figure 3 (Struszczyk, 2002; Hayes et al., 2008). The source of natural chitin used to produce chitosan affects the production parameters and chitosan preparations. Differences in the chitosan production process (e.g., temperature, alkali concentration, ratio of alkali solutions to the shells) also mean that chitosan preparations consist of a mixture of chitosan varying in molecular weight and degree of $\mathrm{N}$-acetylation. Those produced from chitin may also contain impurities such as heavy metals, protein residues and acid/alkaline residues (Kumirska et al., 2010). 


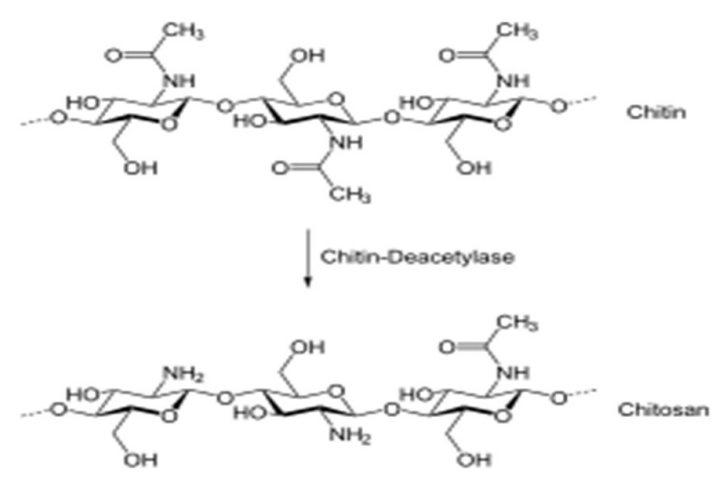

Figure 3. Conversion of chitin to chitosan

However, the problem of poor stability of chitosan-based systems restricts its practical applicability; thus, it has become a great challenge to establish sufficient shelf-life for chitosan formulations. Improved stability can be assessed by controlling the environmental factors, manipulating processing conditions (e.g., temperature), introducing a proper stabilizing compound during extraction of chitin and conversion to chitosan, developing chitosan blends with another polymer, or modifying the chitosan structure using chemical or ionic agents.

The age long use of inorganic bases such as $\mathrm{NaOH}$ or $\mathrm{KOH}$ as agent of deproteination and deacetylation in the extraction process of chitosan became a subject of interest as probable contributing factor for the instability of chitosan. Therefore, the use of diethylamine as an organic base in place of sodium hydroxide or potassium hydroxide in the extraction process was adopted in the current work. The basic nature of diethylamine is due to the presence of lone pair of electrons on the nitrogen atom. This lone pair of electrons is donated to the proton of an acid for a new bond.

In some parts of Nigeria, crabs are local delicacies utilized in making soup. However, the shells are not known to serve any useful purpose and form a component of waste materials from kitchens. The utilization of the shells in chitosan production is a very promising waste to wealth research.

Therefore, the extraction of chitosan from the shell of Scylla serrata using diethylamine as agent of deproteination and deacetylation to a quality that meets high specifications of all industrial applications is the focus of this research. The aim is to find alternative agent for deproteination and deacetylation in the production of high quality chitosan with the right stability to meet the challenges encountered in the commercial use of chitosan.

\section{Materials and Methods}

2.1 Preparation of the sample

The crab shells obtained from Mebe waterside in Bonny Local Government Area of Rivers State, South-South Nigeria were washed thoroughly with distilled water and dried in an oven to constant weight at $40{ }^{\circ} \mathrm{C}$

\subsection{Chitin extraction}

Chitin was extracted from $100 \mathrm{~g}$ of the dried and size reduced shells by demineralisation and deproteination. Demineralization was carried out at ambient temperature using $0.5 \mathrm{M}$ hydrochloric acid (HCl). Evolution of gas indicates the presence of carbonate in the sample and so the treatment was repeated several times until the evolution of gas ceased. The resulting substance was then washed with distilled water up to neutrality, dried in an oven at $40{ }^{\circ} \mathrm{C}$ until a constant weight was obtained. Deproteination was carried out by soaking the dried sample in $0.5 \mathrm{M}$ diethylamine $\left[\left(\mathrm{C}_{2} \mathrm{H}_{5}\right)_{2} \mathrm{NH}\right]$ solution at $30^{\circ} \mathrm{C}$ for $16 \mathrm{hrs}$. The treatment was repeated several times before washing with distilled water to neutrality and then dried at $40^{\circ} \mathrm{C}$ until constant weight was achieved to obtain chitin.

\subsection{Deacetylation of chitin}

Chitosan was obtained by the removal of acetyl group (deacetylation) in the chitin structure. The chitin was then ground and screened with $150 \mu \mathrm{m}$ sieve. Deacetylation was achieved by steeping (soaking) the chitin sample in 12.5 $\mathrm{M}$ diethylamine solution for four days to degrade the chitin. The sample was then heated in a fresh alkaline solution at $100{ }^{\circ} \mathrm{C}$ and at atmospheric pressure for $5 \mathrm{hrs}$. The wet sample was dried at $40{ }^{\circ} \mathrm{C}$ until constant weight 
was achieved to obtain chitosan. The extracted chitosan was soaked in $1 \mathrm{M}$ acetic acid after stirring vigorously and allowed to stand for some time.

\subsection{Proximate analysis}

Proximate analysis of the chitin and chitosan was carried out to determine moisture, ash, protein and fat contents. The sample was dried to a constant weight at $60{ }^{\circ} \mathrm{C}$ in an oven and the weight loss gives the amount of moisture in the samples. Samples were burned in a furnace at temperature of $1000{ }^{\circ} \mathrm{C}$ and weighed to determine the ash content. The fat and protein contents were determined by their respective standard methods (AOAC, 1990; Isa et al., 2012).

\subsection{Carbon/Nitrogen ratio determination}

The Walkley-black and Kjekdahl methods as described by Chan et al. (1995) and Saez-Plaza et al. (2013) were used to quantify organic carbon and nitrogen contents respectively in the extracted chitosan. The carbon/nitrogen was used in determining the DDA of the chitosan sample using the Kasaai equation (equation 1) employed by Abdou et al., (2008).

DDA $(\%)=1.7143$

\subsection{Active compounds determination}

Fourier Transform Infrared Spectroscopy using FTIR-8400S spectrophotometer (Shimadzu) machine was used to determine the active compounds in the samples according to a protocol published by Palpandi et al. (2009).

\section{Results and Discussion}

3.1 Composition, Proximate Analysis and Degree of deacetylation

Tables 1 and 2 present the results of Scylla serrata shell composition and proximate analysis of chitin and chitosan respectively. Table 3 shows carbon- nitrogen content of Scylla serrata shell chitosan. As shown in Table 1, the Scylla serrata shell was found to contain $31.52 \%$ of chitin which is higher than $23.25 \%$ and $21.53 \%$ as reported by Abdulkarim et al. (2013) for mussel shell and Abdou et al. (2008) for shrimp shell respectively. This may be due to variation in mineral content of different water bodies in which these crustaceans strive in. The mineral content $\left(\mathrm{CaCO}_{3}\right)$ of the shell was found to be $32.84 \%$. This mineral content is lower than $51.62 \%$ obtained by Abdulkarim et al. (2013) from mussel shell and 85.90\% from oyster cuticle and higher than 20-30\% from shrimp as reported by Abdou et al. (2008) but falls within the range (30-50\%) reported by Aranaz et al. (2009). Thus, it can be said that the mineral content of the Scylla serrata shell varies in different members of the crustaceans and also varies with location and environment of harvest. Location and environment of harvest had been implicated in several studies as candidates responsible for variations in contaminant burdens or purity levels of extracts from different biota. For example, in a study carried out by Okafor et al. (2020) which investigated the levels of polycyclic aromatic hydrocarbons contaminants in beers, pyrene was detected in a beer sample brewed with Garcinia kola seeds extract and the authors attributed the contamination of the beer to the location and environment of harvest of the Garcinia kola seeds.

Table 1. Scylla serrata shell composition

\begin{tabular}{ll}
\hline Component & Composition (\%) \\
\hline Protein & 14.25 \\
Mineral & 32.84 \\
Chitin & 31.52 \\
Chitosan & 21.39 \\
\hline
\end{tabular}


The moisture content of chitin was very much higher than that of the chitosan (Table 2). This was expected since water in the chitin was dried to constant weight before the deacetylation process. The ash content of chitin was lower than that of chitosan. This could be attributed to the presence of the acetyl group in the chitin sample. This result was in agreement with those reported by Isa et al. (2012) and Abdulkarim et al. (2013). Protein content of the chitosan sample was considered lower after deprotienation of the chitin and this could be attributed to the high degree of deacetylation of the chitin. The report on protein content was not in agreement with what Abdulkarim et al. (2013) reported.

Table 2. Proximate analysis for chitin and chitosan of Scylla serrata shell

\begin{tabular}{lllll}
\hline & Moisture (\%) & Ash (\%) & Fat (\%) & Protein (\%) \\
\hline Chitin & 2.35 & 3.03 & 1.79 & 3.85 \\
Chitosan & 1.65 & 3.84 & 0.53 & 2.80 \\
\hline
\end{tabular}

The carbon-nitrogen analysis gave a chitosan with DDA of $69.24 \%$ which is higher than those reported by Isa $e t$ al. (2012) of 50.64\% for shrimp shell and Abdulkarim et al. (2013) of $60.69 \%$ for mussel shell. The result however is still lower than the reported DDA of $98.38-98.79 \%$ achieved by Kalut (2008). This may be attributed to the nature of the raw material used, its immediate environment and also the methods applied during the processes. Furthermore, the chitosan was found to dissolve completely in $1 \mathrm{M}$ acetic acid after about 45 minutes. There is an indication that chitosan has been extracted in this work, since the necessary conditions as stated by some literature are that the DDA should be about $50 \%$ and that the chitosan should be soluble in acidic media (Honarkar and Barikani, 2009).

Table 3. Carbon and Nitrogen content of chitosan of Scylla serrata shell

\begin{tabular}{cccc}
\hline Carbon (\%) & Nitrogen (\%) & Degree of deacetylation (\%) & Carbon/Nitrogen ratio \\
\hline 18.82 & 3.32 & 69.24 & 5.67 \\
\hline
\end{tabular}

\subsection{Characterization of chitin and chitosan using infrared spectroscopy}

In the present work, functional groups and compounds extrapolated from the spectra of chitin (Figure 1) and chitosan (Figure 2) from Scylla serrata shell are presented in Tables 4 and 5 respectively. It is evidence from the data that there were impurities in the extracted chin and chitosan which could be as a result of processing procedure, hence the presence of bromo- and chloro- compounds in the extracted chitin and bromo compound in the chitosan.

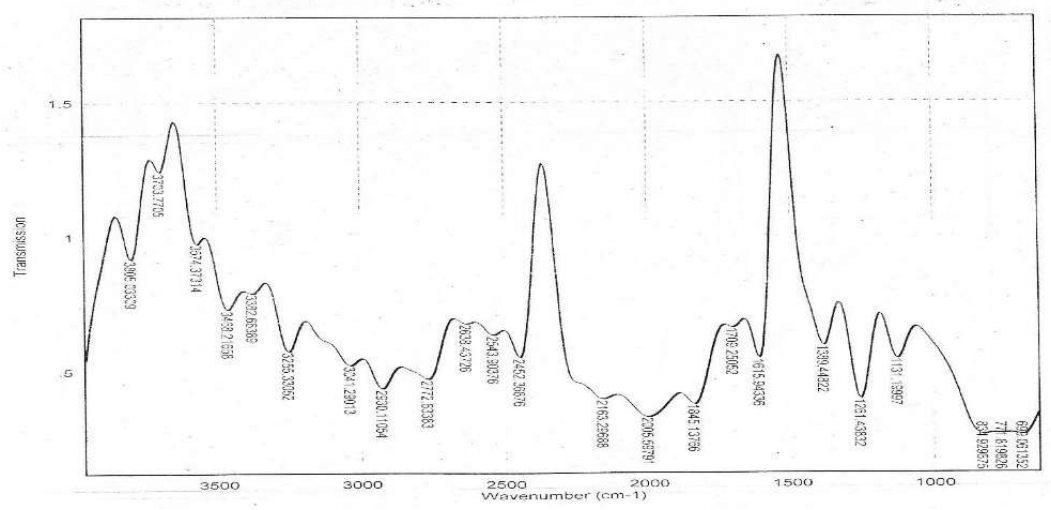

Figure 4. Spectrum of chitin from Scylla serrata shell 
From Table 4 and the FTIR spectrum (Figure 4), there are characteristics bands of $\left(\mathrm{RNH}_{3}\right.$ and $\mathrm{R}_{3} \mathrm{~N}$ ) at $1615.943 \mathrm{~cm}^{-}$ ${ }^{1}$ and $3468.217 \mathrm{~cm}^{-1}$ respectively; the hydroxyl group band at $3041.290 \mathrm{~cm}^{-1}$ to $3805.033 \mathrm{~cm}^{-1}$, and carbonyl group band at $2163.297 \mathrm{~cm}^{-1}$. Thus, the presence of these functional groups indicates success in chitin production.

Table 4. FTIR results of chitin extracted from Scylla serrata shell

\begin{tabular}{|c|c|c|c|}
\hline $\mathbf{S} / \mathbf{N}$ & Wavelength $\left(\mathrm{cm}^{-1}\right)$ & $\begin{array}{l}\text { Functional } \\
\text { Group }\end{array}$ & Compounds \\
\hline 1 & 699.0614 & $\mathrm{C}-\mathrm{Br}$ & Bromo compound $\mathrm{C}$-Br stretch \\
\hline 2 & 771.8198 & $\mathrm{C}-\mathrm{Br}$ & Bromo compound $\mathrm{C}-\mathrm{Br}$ stretch \\
\hline 3 & 834.9297 & C-CI & Chloro compound C-CI stretch \\
\hline 4 & 1131.200 & $\mathrm{R}-0-\mathrm{R}$ & Ether $\mathrm{C} 0$ stretch \\
\hline 5 & 1261.438 & $\mathrm{R}-0-\mathrm{R}$ & Ether $\mathrm{C} 0$ stretch \\
\hline 6 & 1389.446 & $\mathrm{H}_{2} \mathrm{C}-\mathrm{CH}_{3}$ & Ethane CH stretch \\
\hline 7 & 1615.943 & $\mathrm{RNH}_{3}$ & $1^{0}$ amine $\mathrm{NH}$ stretch \\
\hline 8 & 1709.251 & $\mathrm{R}-0-\mathrm{R}$ & Cyclic ester $\mathrm{C} 0$ stretch \\
\hline 9 & 1845.138 & R-0-R & Cyclic ester C0 stretch \\
\hline 10 & 2005.598 & $\mathrm{RC} 00 \mathrm{H}$ & Carboxylic acid C0 stretch \\
\hline 11 & 2163.297 & $\mathrm{R}_{2} \mathrm{C}=0$ & Carbonyl C0 stretch \\
\hline 12 & 2452.369 & $\mathrm{R}-\mathrm{C} \equiv \mathrm{N}$ & Nitriles CN stretch \\
\hline 13 & 2543.904 & $\mathrm{CH}_{2} \mathrm{SH}$ & Thiol SH stretch \\
\hline 14 & 2683.437 & $\mathrm{CH}_{2}$ & Methylene $\mathrm{CH}$ stretch \\
\hline 15 & 2772.634 & $\mathrm{CH}_{2}$ & Methylene $\mathrm{CH}$ stretch \\
\hline 16 & 2930.111 & $\mathrm{R}-\mathrm{S}-\mathrm{C} \equiv \mathrm{N}$ & Thiocyanate SCN stretch \\
\hline 17 & 3041.290 & $\mathrm{RCHOH}$ & $1^{0}$ alcohol $0 \mathrm{H}$ stretch \\
\hline 18 & 3255.331 & $\mathrm{R}_{2} \mathrm{CHOH}$ & $2^{0}$ alcohol $0 \mathrm{H}$ stretch \\
\hline 19 & 3382.664 & $\mathrm{RCHOH}$ & $1^{0}$ alcohol $0 \mathrm{H}$ stretch \\
\hline 20 & 3468.217 & $\mathrm{R}_{3} \mathrm{~N}$ & $3^{0}$ amine $\mathrm{NH}$ stretch \\
\hline 21 & 3574.373 & $\mathrm{R}_{3} \mathrm{CHOH}$ & $3^{0}$ alcohol $0 \mathrm{H}$ stretch \\
\hline 22 & 3703.771 & $\mathrm{R}_{3} \mathrm{CHOH}$ & $3^{0}$ alcohol $0 \mathrm{H}$ stretch \\
\hline 23 & 3805.033 & $\mathrm{R}_{3} \mathrm{CHOH}$ & $3^{0}$ alcohol $0 \mathrm{H}$ stretch \\
\hline
\end{tabular}

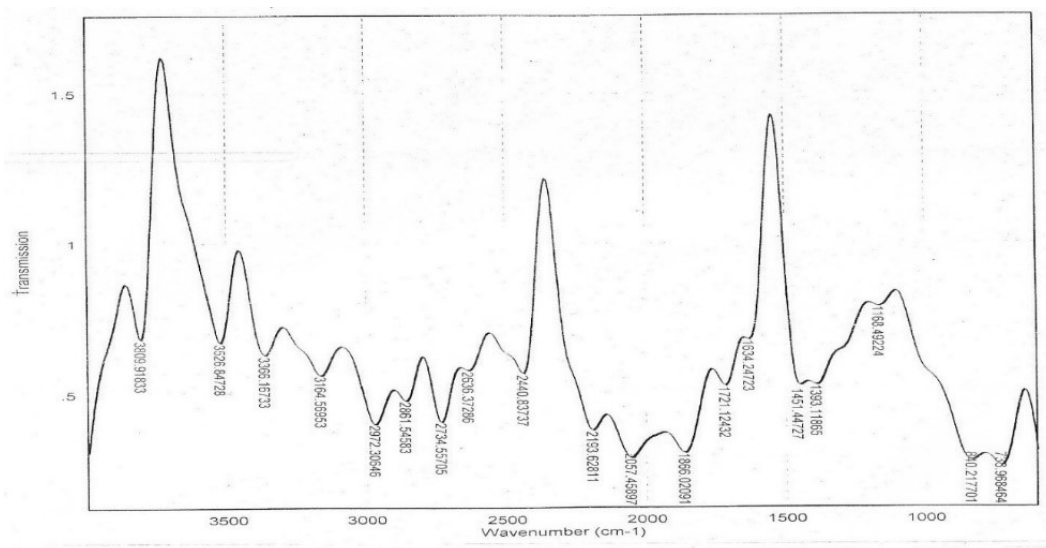

Figure 5. Spectrum of chitosan from Scylla serrata shell

From the FTIR spectrum shown in Figure 5 and the result in Table 5, the absorption peak observed at $3574.373 \mathrm{~cm}^{-}$ $1,3703.771 \mathrm{~cm}^{-1}$ and $3805.033 \mathrm{~cm}^{-1}$ corresponds to the intermolecular hydrogen bonded $\mathrm{OH}$ stretching in alkanols. The peak obtained at $1615.943 \mathrm{~cm}^{-1}$ confirms the presence of NH stretching in primary amine and the band obtained at $2683.437 \mathrm{~cm}^{-1}$ and $2772.634 \mathrm{~cm}^{-1}$ correspond to $\mathrm{CH}$ stretching in methylene group. The FTIR result shows the presence of the functional groups in chitosan structure hence confirming the formation of chitosan. 
Table 5. FTIR results of chitosan extracted from Scylla serrata shell

\begin{tabular}{|c|c|c|c|}
\hline $\mathbf{S} / \mathbf{N}$ & Wavelength $\left(\mathrm{cm}^{-1}\right)$ & Functional Group & Compounds \\
\hline 1 & 733.9685 & $\mathrm{C}-\mathrm{Br}$ & Bromo compound $\mathrm{C}-\mathrm{Br}$ stretch \\
\hline 2 & 840.2177 & $\mathrm{R}-0-\mathrm{R}$ & Ether $\mathrm{C} 0$ stretch \\
\hline 3 & 1168.492 & $\mathrm{R}-0-\mathrm{R}$ & Ether $\mathrm{C} 0$ stretch \\
\hline 4 & 1393.119 & $\mathrm{R}-0-\mathrm{R}$ & Ether $\mathrm{C} 0$ stretch \\
\hline 5 & 1451.447 & $\mathrm{H}_{2} \mathrm{C}-\mathrm{CH}_{3}$ & Ethane $\mathrm{CH}$ stretch \\
\hline 6 & 1634.247 & $\mathrm{RNH}_{3}$ & $1^{0}$ amine $\mathrm{NH}$ stretch \\
\hline 7 & 1721.124 & $\mathrm{R}-0-\mathrm{R}$ & Cyclic ester C0 stretch \\
\hline 8 & 1866.021 & $\mathrm{R}-0-\mathrm{R}$ & Cyclic ester C0 stretch \\
\hline 9 & 2057.459 & $\mathrm{RC} 00 \mathrm{H}$ & Carboxylic acid $\mathrm{C} 0$ stretch \\
\hline 11 & 2440.837 & $\mathrm{R}-\mathrm{C} \equiv \mathrm{N}$ & Nitriles CN stretch \\
\hline 12 & 2636.373 & $\mathrm{CH}_{2}$ & Methylene $\mathrm{CH}$ stretch \\
\hline 13 & 2734.557 & $\mathrm{CH}_{2}$ & Methylene $\mathrm{CH}$ stretch \\
\hline 14 & 2861.546 & $\mathrm{CH}_{2}$ & Methylene $\mathrm{CH}$ stretch \\
\hline 15 & 2972.306 & $\mathrm{CH}_{2}$ & Methylene $\mathrm{CH}$ stretch \\
\hline 16 & 3164.570 & $\mathrm{RCHOH}$ & $1^{0}$ alcohol $0 \mathrm{H}$ stretch \\
\hline 17 & 3366.167 & $\mathrm{RCHOH}$ & $1^{0}$ alcohol $0 \mathrm{H}$ stretch \\
\hline 18 & 3526.847 & $\mathrm{R}_{3} \mathrm{CH} 0 \mathrm{H}$ & $3^{0}$ alcohol $0 \mathrm{H}$ stretch \\
\hline 19 & 3809.918 & $\mathrm{R}_{3} \mathrm{CH} 0 \mathrm{H}$ & $3^{0}$ alcohol $0 \mathrm{H}$ stretch \\
\hline
\end{tabular}

However, $\mathrm{CH}_{3}$ waging along chain $\left(952 \mathrm{~cm}^{-1}\right)$, CO stretching at $1026 \mathrm{~cm}^{-1}$ and $1073 \mathrm{~cm}^{-1}$, and amide II band (1563 $\mathrm{cm}^{-1}$ ) were not found in chitin extracted from Scylla serrata shell after diethylamine deproteination when compared to a standard $\alpha$-chitin. In the extracted chitosan from Scylla serrata, $\mathrm{HPO}_{4}{ }^{2-}$ and amide III were also not found when in comparison with standard chitosan. Table 6 shows the wave length of the main bands obtained for standard chitin and extracted chitin from Scylla serrata while Table 7 shows those of standard chitosan and extracted chitosan from Scylla serrata.

Table 6. Wave length for standard $\alpha$-chitin and chitin extracted from Scylla serrata shell

\begin{tabular}{|c|c|c|}
\hline & Wavenumber & \\
\hline Vibration modes & *Standard $\alpha$-chitin & Scylla serrata \\
\hline OH out-of- plane bending & 690 & 699.0614 \\
\hline NH out-of- plane bending & 752 & 771.8198 \\
\hline Ring stretching & 896 & 834.9297 \\
\hline $\mathrm{CH}_{3}$ waging along chain & 952 & - \\
\hline CO stretching & 1026 & - \\
\hline CO stretching & 1073 & - \\
\hline Asymmetric in- phase ring stretching mode & 1116 & 1131.200 \\
\hline $\mathrm{CH}_{2}$ bending and $\mathrm{CH}_{3}$ deformation & 1418 & 1389.446 \\
\hline Amide II band & 1563 & - \\
\hline Amide I band & 1661 & 1615.943 \\
\hline $\mathrm{CH}$ stretching & 2878 & 2772.634 \\
\hline Symmetric $\mathrm{CH}_{3}$ stretching and asymmetric $\mathrm{CH}_{2}$ stretching & 2930 & 2930.111 \\
\hline NH stretching & 3268 & 3255.331 \\
\hline OH stretching & 3439 & 3382.664 \\
\hline
\end{tabular}

*Source: Palpandi et al., 2009 
Table 7. Wave length of the main bands obtained for standard chitosan and chitosan extracted from Scylla serrata shell

\section{Wavenumber $\left(\mathrm{cm}^{-1}\right)$}

\begin{tabular}{|c|c|c|}
\hline Vibration modes & *Standard chitosan & Chitosan from Scylla serrata shell \\
\hline $\mathrm{HPO}_{4}{ }^{2-}$ & 891.41 & - \\
\hline Amide III & 897.41 & - \\
\hline $\mathrm{PO}_{4}{ }^{3-}$ & 1026.63 & 1168.492 \\
\hline $\mathrm{PO}_{3}^{4-}$ & 1259.54 & 1393.119 \\
\hline OH group (monomer) & 1422.73 & 1451.447 \\
\hline$\left(-\mathrm{NH}_{2}\right)$ Amide II & 1587.94 & 1634.247 \\
\hline Structural unit & 3377.95 & 3366.170 \\
\hline
\end{tabular}

*Source: Palpandi et al. (2009)

\section{Conclusions and Recommendation}

It is shown that Scylla serrata shell contained appreciable amounts of protein, mineral, chitin and chitosan. Demineralisation, deproeination and deactylation yielded a chitosan with degree of deatylation of $69.24 \%$. FTIR characterization gave intermolecular hydrogen bonded $\mathrm{OH}$ stretching in alkanols, $\mathrm{NH}$ stretching in primary amine and $\mathrm{CH}$ stretching in methylene group confirming the presence of active compounds in the extracted chitosan. This study has shown that diethylamine (organic base) has great potential as agent of deproteination and deacetylation in the extraction of chitosan from Scylla serrata shell. Consequently, academic activity in the area of investigation of the stability of the extracted chitosan from Scylla serrata shell using diethylamine as agent of deproeination and deactylation is strongly recommended.

\section{References}

1. Abdou, E. S., Nagy, K. S. A. \& Elsabee, M. Z. (2008). "Extraction and characterization of chitin and chitosan from local sources”. Biresources Technology, 9, 1359-1367.

2. Abdulkarim, A., Isa, M. T., Abdulsalam, S., Muhammad, A. J. \& Ameh, A. O. (2013). "Extraction and characterisation of chitin and chitosan from mussel shell". Civil and Environmental Research, 3(2), 108-114.

3. Al Sagheer, F. A., Al-Sughayer, M. A., Muslim, S. \& Elsabee, M. Z. (2009). "Extraction and characterization of chitin and chitosan from marine sources in Arabian Gulf”. Carbohydr. Polym., 77, 410-419.

4. AOAC. (1990). "Official Methods of Analysis, $15^{\text {th }}$ eds. Association of Official Analytical Chemists": Washington, DC.

5. Aranaz, I., Mengíbar, M., Harris, R., Paños, I., Miralles, B., Acosta, N., Galed, G. \& Heras Á. (2009). "Functional characterization of chitin and chitosan". Curr. Chem. Biol., 3, 203-230.

6. Bordi, F., Cametti, C. \& Paradossi, G. (1991). "Dielectric behavior of polyelectrolyte solutions: the role of proton fluctuation". J. Phys. Chem., 95, 4883-4889.

7. Brunner, E., Ehrlich, H., Schupp, P., Hedrich, R., Hunoldt, S., Kammer, M., Machill, S., Paasch, S., Bazhenov, V. V., Kurek, D. V. Arnold, T., Brockmann, S., Ruhnow, M. \& Born, R. (2009).” Chitin based scaffolds are an integral part of the skeleton of the marine demosponge Ianthella basta." J. Struct. Biol., 168, 539-547. 
8. Campana-Filho, S. P., De Britto, D., Curti, E., Abreu, F. R., Cardoso, M. B., Battisti, M.V., Sim, P.C. \& Lavall, R. L. (2007). "Extraction, structures and properties of $\alpha$ - and $\beta$-chitin". Quim. Nova, 30, 644 650 .

9. Chan, Y. C., Vowles, P. D., McTainsh, G. H., Simpson, R. W., Cohen, D. D. \& Bialey, G. M. (1995). "Use of modified walkley-black method to determine the organic and elemental carbon content of urban aerosols collected on glass fibre filters". Chemosphere, 31(11-12), 44034411.

10. Coates, J. (2000). "Interpretation of Infrared Spectra, A Practical Approach": In Meyers, R.A. (ed.) Encyclopedia of Analytical Chemistry, Newtown, USA: John Wiley \& Sons Ltd, Chichester.

11. Darmon, S. E. \& Rudall, K. M. (1950). "Infra-red and X-ray studies of chitin. Disc". Faraday Soc., 9, 251-260.

12. Dash, M., Chiellini, F., Ottenbrite, R. M. \& Chiellini, E. (2011). "Chitosan — a versatile semi-synthetic polymer in biomedical applications”. Prog. Polym. Sci., 36, 981-1014.

13. Duarte, M. L., Ferreira, M. C., Marvao, M. R. \& Rocha, J. (2001). "Determination of the degree of acetylation of chitin materials by 13C CP/MAS NMR spectroscopy”. Int. J. Biol. Macromol., 28, 359363.

14. Duarte, R., Krovvidi, K. R. \& Khan, A. A. (1998). "Solubility parameter of chitin and chitosan". Carbohydr. Polym., 36, 121-127.

15. Focher, B., Naggi, A., Torri, G., Cosani, A. \& Terbojevich, M. (1992). "Structural differences between chitin polymorphs and their precipitates from solutions-evidence from CP-MAS 13CNMR, FT-IR and FT-Raman spectroscopy". Carbohydr. Polym., 17, 97-102.

16. Hayes, M., Carney, B., Slater, J. \& Brück, W. (2008). "Mining marine shellfish wastes for bioactive molecules: chitin and chitosan -Part A: extraction methods". Biotechnol. J., 3, 871-877.

17. Hoemann, C. D., Sun, J., Légaré, A., McKee, M. D. \& Buschmann, M. D. (2005). “Tissue engineering of cartilage using an injectable and adhesive chitosan-based cell-delivery vehicle". Osteoarthritis Cartilage, 13, 318-329.

18. Honarkar, H. \& Barikani, M. (2009). “Application of biopolymers I: chitosan”. Monnbatsh Chemistry. 1(40), 1403-1420.

19. Hurler, J. \& Škalko-Basnet, N. (2012). "Potentials of chitosan-based delivery systems in wound therapy". Bioadhesion study. J. Funct. Biomater, 3, 37-48.

20. Ifuku, S. (2014). "Chitin and chitosan nanofibers: preparation and chemical modifications". Molecules, 19, 18367-18380.

21. Isa, M. T., Ameh, A. O., Tijani M. \& Adama, K. K. (2012). "Extraction and characterization of chitin and chitosan from Nigerian shrimps". Int. J. Biol. Chem. Sci., 6(1): 446-453.

22. Jeuniaux, C. (1996). "A brief survey of the early contribution of European scientists to chitin knowledge". In: Domard A, Jeuniaux C, Muzzarelli RAA, Roberts, editors. Advances in chitin Sciences. Jacques Andre Publ, Lyon, France, 1-9.

23. Juárez-de la Rosa, B.A., Ardisson, P. L., Azamar-Barrios, J. A., Quintana, P. \& Alvarado-Gil, J. J. (2007). "Optical, thermal, and structural characterization of the sclerotized skeleton of two antipatharian coral species”. Mater. Sci. Eng., 27, 880-885.

24. Kalut, S. A. (2008). "Enhancement of degree of deacetylation of chitin in chitosan production". $B$. Chem. Eng. Thesis, Universiti Malaysia Pahang, 5-31.

25. Kim, I. Y., Seo, S. J.; Moon, H. S., Yoo, M. K., Park, I. Y., Kim, B. C. \& Cho, C. S. (2008). "Chitosan and its derivatives for tissue engineering applications". Biotechnol. Adv., 26, 1-21.

26. Kumirska J., Czerwicka M., Kaczyński Z., Bychowska A., Brzozowski K., Thöming J. \& Stepnowski P. (2010). "Application of spectroscopic methods for structural analysis of chitin and chitosan". Marine Drugs, 8, 1567-1636.

27. Kurita, K. (2006). "Chitin and chitosan: functional biopolymers from marine crustaceans". Marine Biotechnology, 8(3), 203-226.

28. Lertsutthiwong, P., How, N.C., Chandrkrachang, S. \& Stevens, W.F. (2002).” Effect of chemical treatment on the characteristics of shrimp chitosan", Journal of Metals, Materials and Minerals, 12 (1), 11-18. 
29. Limam, Z., Selmi, S., Sadok S. \& El Abed A. (2011). "Extraction and characterization of chitin and chitosan from crustacean by-products: biological and physicochemical properties". African Journal of Biotechnology, 10(4), 640-647.

30. Muzzarelli, R. A. A. \& Muzzarelli, C. (2009). "Chitin and chitosan hydrogels", 849-888.

31. Noishiki, Y., Takami, H., Nishiyama, Y., Wada, M., Okada, S. \& Kuga, S. (2003). "Alkali-induced conversion of $\beta$-chitin to $\alpha$-chitin". Biomacromolecules, 4, 896-899.

32. Okafor, V. N, Uche, U. B. \& Abailim, R. C. (2020). "Levels of polycyclic aromatic hydrocarbons (PAHs) in beers: consumption and public health concerns". Chemical Science International Journal, 29 (1), 47-49.

33. Okamoto, Y., Yano, R., Miyatake, K., Tomohiro, I., Shigemasa, Y. \& Minami, S. (2003). "Effects of chitin and chitosan on blood coagulation". Carbohydr. Polym., 53, 337-342.

34. Palpandi, C., Shanmugam, V. \& Shanmugam, A. (2009). "Extraction of chitin and chitosan from shell and operculum of mangrove gastropod Nerita (Dostia) crepidularia Lamarck". International Journal of Medicine and Medical Sciences; 1(5), 198-205.

35. Pearson, F. G., Marchessault, R. H. \& Liang, C. Y. (1960). "Infrared spectra of crystalline polysaccharides. V. Chitin”. J. Polym. Sci., 13, 101-116.

36. Rinaudo, M. (2006). "Chitin and chitosan: Properties and applicatio". In Philips GO, Williams PA, editors. Handbook of Hydrocolloids, Woodhead publishing Ltd; UK ns. Prog. Polym. Sci.,31, 603-632.

37. Rinaudo, M. (2008). "Main properties and current applications of some polysaccharides as biomaterials". Polym. Int., 57, 397-430.

38. Rinaudo, M. (2012). "Physical properties of chitosan and derivatives in sol and gel states": In ChitosanBased Systems for Biopharmaceuticals: Delivery, Targeting and Polymer Therapeutics; Sarmento, B., das Neves, J., Eds.; John Wiley \& Sons: Chichester, UK; 23-44.

39. Rinaudo, M. (2014). "Materials based on chitin and chitosan". In Bio-Based Plastics: Materials and Applications; Kabasci, S., Ed.; John Wiley \& Sons: Chichester, UK; 63-80.

40. Roberts, G.A.F. (1992). "Chitin Chemistry", 1st ed.; MacMillan: London, UK

41. Saez-Plaza, P., Navas, M. J., Wybraniec, S., Michalowski, T., \& Asuero, A. G. (2013). “An overview of the kjeldahl method of nitrogen determination. Part II. Sample preparation, working, scale, instrumental finish and quality control". Critical Reviews in Analytical Chemistry, 43, 234-272.

42. Shirai, K., Palella, D., Castro, Y., Guerrero-Legarreta, I., Saucedo-Castaneda, G., Huerta-Ochoa, S. \& Hall, G. M. (1998). "Characterization of chitins from lactic acid fermentation of prawn wastes": In Advances in Chitin Science; Chen, R.H., Chen, H.C., Eds.; Elsevier: Taiwan, Volume III: 103-110.

43. Struszczyk, M. H. (2002). "Chitin and chitosan: part I.- properties and production". Polimery, 47, 316325.

44. Synowiecki, J. \& Al-Khateeb, N. A. (2003). "Production, properties and some new applications of chitin and its derivatives". Food Sci. Nutr., 43, 145-171.

45. Szymańska, E. \& Winnicka, K. (2012). "Preparation and in vitro evaluation of chitosan microgranules with clotrimazole". Acta Pol. Pharm. Drug Res., 69, 509-513.

46. Szymańska E. \& Winnicka K. (2015). "Stability of chitosan - a challenge for pharmaceutical and biomedical applications". Mar. Drugs, 13, 1819-1846.

47. Venkatesan, J., Bhatnagar, I. \& Kim, S. K. (2014). "Chitosan-alginate biocomposite containing fucoidan for bone tissue engineering”. Mar. Drugs; 12, 300-316.

48. Younes, I. \& Rinaudo, M. (2015). "Review of chitin and chitosan preparation from marine sources: Structure, properties and applications", Mar. Drugs 13, 1133-1174. 